\title{
RIGHTS OF FUTURE INTEREST AS MATRIMONIAL PROPERTY: SPECIAL REFERENCE TO EARNING CAPACITY
}

\author{
Norliah Ibrahim* \\ Zuhairah Ariff Abd Ghadas**
}

\begin{abstract}
Traditionally, the claims of matrimonial property are mainly confined to existing and personal property which exist or were acquired during the marriage prior to the divorce, such as buildings, land, vehicles, etc. However, with the changes in the economic sources and social behaviour of the modern society, whereby earnings and proprietary rights are no longer confined to merely property but also include future interest and future earnings such as investments, trust fund and business ventures, it is perceived that the scope of claims on matrimonial property shall also be revolutionised to include claims in future earnings of the divorced parties.

This paper discusses the legal principle which the court could apply when it comes to claims on future interest as matrimonial property. The case law analysis is merely confined to the Malaysian precedents and the analogy of
\end{abstract}

\footnotetext{
Assistant Professor of Law,, Ahmad Ibrahim Kulliyyah of Laws, International Islamic University Malaysia, Email: norliah@iium.edu.my.

** Professor of Law, Faculty of Law and International Relations, Universiti Sultan Zainal Abidin, Email: zuhairah@unisza.edu.my
} 
human capital earnings is used by the writers to justify the possibility of claims in all types of future earnings as matrimonial property.

Keywords: matrimonial property, future earnings, Malaysia, human capital, earnings in business

\title{
FAEDAH MASA HADAPAN SEBAGAI HARTA SEPENCARIAN: RUJUKAN KHAS KEPADA KAPASITI PENDAPATAN
}

\begin{abstract}
ABSTRAK
Secara tradisinya, kebanyakan kes tuntutan harta sepencarian adalah terbatas kepada harta yang sedia ada atau milik peribadi yang diperolehi atau terkumpul sepanjang perkahwinan sebelum berlakunya sesuatu perceraian, seperti rumah, bangunan, tanah dan kenderaan. Walau bagaimanapun, dengan perkembangan ekonomi semasa, sumber-sumber pendapatan dan perilaku sosial masyarakat moden, hak milik tidak lagi terhad kepada pemilikan tradisional tetapi juga termasuk faedah pulangan atau pendapatan masa depan yang diperolehi daripada pelaburan, dana amanah dan perniagaan, adalah dirasakan bahawa skop tuntutan ke atas harta sepencarian hendaklah juga diperluaskan termasuklah tuntutan terhadap pulangan serta keuntungan yang akan diperolehi pada masa akan datang dari pihak-pihak yang bercerai .

Kertas kerja ini membincangkan prinsip undang-undang yang boleh diaplikasikan oleh mahkamah apabila tuntutan dibuat terhadap faedah atau pulangan serta keuntungan yang diperolehi di masa akan datang sebagai harta sepencarian. Analisis kes adalah terbatas pada kes-kes yang telah diputuskan di Malaysia serta analogi terhadap
\end{abstract}


penghasilan modal insan bagi membenarkan kemungkinan tuntutan dalam semua jenis pendapatan masa depan sebagai harta sepencarian.

Kata kunci: harta sepencarian , pendapatan masa depan , Malaysia, modal insan, pendapatan dalam perniagaan.

\section{INTRODUCTION}

In many instances of marriage breakdown, one of the most valuable economic assets is the earning capacity of one or both parties. It has been a subject for discussion in several jurisdictions whether such earning power constitutes a form of "property" divisible between husband and wife on divorce. ${ }^{1}$ This claim is based on the fact that in a normal situation, an individual enters into a marriage with certain skills, talents, education and training which they acquired prior to their marriage and it is enhanced during their marriage in which both parties must contribute financially or non-financially. Economists and sociologists often refer to these personal attributes which may lead to future income, as "human capital". ${ }^{2}$ It is argued that although it is an undeniable fact that both spouses enter a marriage with their distinct human capital, the attainment of additional human capital during the marriage will often lead to "enhanced earning capacity" for only one spouse. Typically, as one spouse (the "enhanced spouse") acquires enhanced earning capacity, the other spouse (the "investing spouse"), may defer his or her own career opportunities and accept a temporary reduction in her standard of living to support the enhanced spouse. In expectation of future income to be derived from her investment in her spouse's human capital, the wife may be fully prepared to endure these sacrifices. Nonetheless, when the marriage ends, the investing spouse will be left without a return on her investment unless

1 Kevin J. Gray, Reallocation of property on divorce, (Professional Books, 1977), 169. According to him in some jurisdictions, factors related to earning capacity are merely regarded as relevant considerations in the equitable distribution of other property.

2 Wildstein D.A., and Vuotto Jr.C,F., Enhanced Earning Capacity :Is an Asset Subject to Equitable Distribution Under New Jersey Law?, Retrieved from http://www.divorcemag.com/NJ/proforum/ enhancedearningcapacity.html. 
the enhanced earning capacity of the other spouse is valued as property, specifically matrimonial property and subject to division upon divorce.

The question whether human capital is property within the context of marriage and divorce has been a "hot" topic since the early seventies ${ }^{3}$ and is probably made most often with respect to an educational degree or professional license, even though logically it should be applicable as well to any enhancement of earning capacity that occurs during marriage. ${ }^{4}$

\section{HUMAN CAPITAL AS PROPERTY}

Essentially human capital, which refers to an individual's expected future earnings, can be seen as an asset that promises a return on investments such as education, training, and work experience. It is an investment of time and money in self-development to enhance skills and abilities, which are a source and form of wealth. ${ }^{5}$ It consists of intangibles such as skills, knowledge, and ability acquired through education, training or experience, which may be manifested by a degree, a license, by reputation, or a resume. Lenore Weitzman observes that a modern conception of marital property might well be broadened to include the 'earning power' of the marital partners. The recognition of earning power as marital property would legitimately compensate a non-income earning spouse for contributing to the other's education, employability and job success". ${ }^{6}$

The significance of recognising human capital as property evolved from the changing nature of property itself. Weitzman noted that people today invest more in human capital and career assets

3 Joyce Davis, "Enhanced earning capacity/human capital: the reluctance to call it property", Women's Rights Law Reporter, Vol 17(1996): 109.

$4 \quad$ Milton C. Regan, JR, "Spouses and strangers: divorce obligations and property rhetoric", George Town Law Journal, Vol. 82(1994): 2361.

5 Joyce Davis, "Enhanced earning capacity/human capital: the reluctance to call it property", Women's Rights Law Reporter, Vol 17(1996): 130.

6 Lenore Weitzman, "Legal regulation of marriage: tradition and change", California Law Review, Vol. 62(1974): 1169, 1185. 
instead of investing in land or a family farm. The new property that results from this investment include inter alia enhanced earning capacities which are often the major assets acquired during the marriage. By this, the law must be prepared to expand the definition of property and recognise them as part of dividable matrimonial assets. $^{7}$

The issue whether to recognise or not human capital as a matrimonial property is silent in Malaysia. Without denying the current changes of the economic source it is found that no cases as yet which challenge or argued that it should be included in the definition of matrimonial property and subject to division upon divorce. The words "matrimonial property" has been defined in numerous cases, it is found that earning power or earning capacity was mentioned only by Shankar, J. in the case of Ching Seng Woah v. Lim Shook Lin, ${ }^{8}$ when he said that:

the expressions refer to the matrimonial home and everything which is put into it by either spouse with the intention that their home and chattels should be a continuing resource for the spouses and their children to be used jointly and severally for the benefit of the family as a whole. It matters not in this context whether the asset is acquired solely by the one party or the other or by their joint efforts. Whilst the marriage subsists, these assets are matrimonial assets. Such assets could be capital assets. The earning power of each spouse is also an asset $^{9}$ (emphasis added).

Thus, from the above quotation, it is obvious that earning power has been addressed by the judge to be included in the definition of the matrimonial property without giving any further elaboration.

7 Lenore J. Weitzman, "Marital property: its transformation and division in the United States", in Lenore J. Weitzman and Mavis Maclean, (edit.), Economic consequences of divorce, the international perspective, (Clarendon Press. Oxford, 1992), 86.

$8 \quad$ [1997] 1 MLJ 109.

$9 \quad$ Ibid, at p. 122. 
The English court of Appeal in the case of Wachtel v. Wachtel, ${ }^{10}$ defined "family assets" divisible on dissolution of marriage not only assets "of capital nature", such as the matrimonial home and the furniture in it, but also assets "of a revenue-producing nature, such as the earning power of husband and wife". This shows that the English courts do recognise earning potential as a family asset which Lord Denning proposed that the wife should receive, as a "starting point", one-third of the capital assets of the family and one-third of the spouses' joint earnings. It was pointed out that the rationale for recognising it as a matrimonial property and subject to distribution at the time of divorce is rooted in both social and economic policy when marriage is viewed a socio- economic unit. Thus, efforts of both parties during the marriage has led to the creation of matrimonial property no matter whether it is tangible like bank account, or intangible like goodwill. In other words, the property acquired is a product of investment of the parties which represents a sacrifice in anticipation of greater future income gained as a result of that sacrifice. ${ }^{11}$

\section{ARGUMENTS FOR REJECTING HUMAN CAPITAL OR FUTURE INTEREST AS MATRIMONIAL PROPERTY}

In the United States of America, courts have overwhelmingly rejected attempt to characterise human capital as matrimonial property based on several rationales. The most common rationale offered to deny the claim of property in these cases is that degrees, licenses, and earning power are not property in the usual sense of that term. ${ }^{12}$ It does not fit within the traditional legal conceptions of property in the sense that they cannot, for instance, be assigned, sold, transferred or conveyed. Robert E. Pinnel claimed that a degree, for example has no standard barter

\footnotetext{
[10 [1973] 1 All ER 829.

11 Wildstein D.A., and Vuotto Jr.C,F., Enhanced Earning Capacity : Is an Asset Subject to Equitable Distribution Under New Jersey Law? Retrieved from http://www.divorcemag.com/NJ/proforum/enhanced earning capacity.html.

12 Milton C. Regan, JR, Spouses and strangers: divorce obligations and property rhetoric, 2303.
} 
or exchange value in which it cannot be assigned or sold. It rather personal to in nature which culminated for years by the student spouse and has no current exchange value with no more than expectancy of future income. ${ }^{13}$ Thus, in the case of Graham v. Graham $^{14}$ the court held that M.B.A. degree is not a property as it is simply an intellectual achievement with no exchange value or any objective transferable in an open market. Apart from the fact that it terminates on the death of the holder, it is also inheritable.

Thus, the primary arguments underlying the reluctance to define enhanced earning capacity as property are because it does not fit within the traditional legal conceptions of property. The same principle applies by the court even though the earning power derived by the husband from a college and law school education was financed by the wife. ${ }^{15}$ The case of Hoak v. Hoak ${ }^{16}$ also illustrates the same principle. While recognising that the wife had 'made personal financial sacrifices and postponed her own career plans', the West Virginia Supreme Court of Appeals held that the degree was not subject to division. Even though it is undeniable fact that financial and emotional supports are significant in obtaining a degree, it bears no logical relation to the value of the resulting degree. Instead it primarily results from the effort of the student who earns it.

The difficulties in valuating earning capacity is also a reason relied on by many courts. It cannot be easily quantified like other type of property. In relation to this, the court in the case of Lesman v. Lesman ${ }^{17}$ noted, "it is almost impossible to predict what amount of enhanced earnings, if any, will result from a professional education. The degree of financial success attained by those holding a professional degree varies greatly. Some, even, may earn less from their professional practices than they could have earned from nonprofessional work." The Colorado Supreme Court in the case of In re

$13 \quad$ Robert E . Pinnell, 1979."Divorce after Professional School: Education and Future Earning Capacity May be Marital Property -In re Marriage of Horstmann", Missouri Law Review, Vol 44(2) (1979): $329,331$.

$14 \quad[1978] 574$, P.2d 75.

15 Refer to the case of Todd v. Todd, [1969] 78 Cal. Rptr. 131.

$16 \quad$ [1988]14 FLR 1370.

$17 \quad$ [1982] 452 N.Y.S. $2 d 935$. 
Marriage of Olar $^{18}$ also highlights the same problem by stating that the valuation of future earning capacity is highly speculative since it is dependent on myriad contingencies that might affect how much the individual might earn over the course of a lifetime. There is no guarantee that the spouse with the enhanced education will earn the amounts calculated. In view of this, it can be conceded that one of the major problems is to calculate their worth. While the courts know how to value a family home by relying on its market value, that there are no equally simple formulas for valuing a future earning capacity. Therefore, Weitzman ${ }^{19}$ asserts that since one cannot sell his or her earning capacity, there is no market to establish the value of the new property.

Those who reject the idea that human capital is property also rely on the idea that it is important to have a clean break between the parties at the time of divorce. ${ }^{20}$ Davis clearly argued that by accepting the human capital as property and recognising the wife's entitlement to a share would probably require the husband to make periodic payments as what happened in the $O^{\prime}$ Brien $^{21}$ case where the payments required over ten years. This continued financial entanglement between the parties would make it impossible to have a clean break. ${ }^{22}$

Even though the courts refuse to treat human capital as matrimonial property, most states in the United States for example, New Jersey and Oklahoma have settled on an intermediate approach that recognises the value of the spouse's contribution and tries to

$18 \quad$ [1987] 747 P.2d, 676.

19 Lenore J. Weitzman, "Marital Property: Its transformation and division in the United States", in Economic consequences of divorce, the international perspective, 86.

Mary Hayes and Catherine Williams, Family Law, principles, policy and practice, Second Edition, (Butterworths, London, 1999), 586590; Jill Black, Jane Bridge \& Tina Bond, A practicle approach to Family Law, Sixth Edition, (Blackstone Press ltd., London, 2000), 255; Rodger Hayward Smith and Clive R. Newton, Jackson's Matrimonial Finance and Taxation, Sixth Edition, (Butterworths, London, 1996), 368-369 and Kate Standley, Cases \& Materials on Family Law, (Blackstones Press Ltd.,London, 1997), 168-173.

$21 \quad$ [1985] 66 N.Y 2d. 576.

22 Joyce Davis, "Enhanced earning capacity? Human capital: the reluctance to call it property", 112. 
compensate her. ${ }^{23}$ In other words, the contributing spouse is still remedied by applying four different approaches ${ }^{24}$ which are known as "consideration of non-degree spouse's contribution", "alimony approaches", "progressive approaches" and "division of matrimonial assets in equitable distribution states approach". Thus, the investing spouse can be compensated for her contributions to the enhanced of future interest by some form of alimony award.

\section{ARGUMENTS FOR ACCEPTING HUMAN CAPITAL OR FUTURE INTEREST AS MATRIMONIAL PROPERTY}

Despite the fact that most of the U.S courts are reluctant to accept the human capital as property, it gained recognition by the New York Court of Appeal in the land mark case of O'Brien v. O'Brien. ${ }^{25}$ The parties were married in 1971 when the wife was a grammar school teacher who held a bachelor's degree and a temporary teaching certificate. In order to get permanent certification, she needed another eighteen months of additional study, which she had relinquished in order to support the husband's education. The husband, after completing his training and obtaining a license to practice surgery in October 1980, filed a divorce petition two months later. The wife claimed a share over her husband's medical degree. In accepting expert testimony that the husband's medical license was worth $\$ 472,000$, the court awarded $\$ 188,000$ to the wife which represents $40 \%$ of the value of the license, payable in eleven annual installments. The husband made an appeal claiming that the license was his non-

23 Lenore J. Weitzman, "Marital property: Its transformation and division in the United States", in Economic consequences of divorce, the international perspective, 129.

24 Leslie F. Birns and Gregg A. Grauer, "Human capital as marital property", Hofstra Law Review, vol.19 (1990): 499. Lenore J Wetzman divide it into three different approaches that is "cost incurred: the reimbursement approach, "benefits gained: enhanced earning capacity" and "equity and parity: alimony or an equivalent opportunity". Further details refer to Lenore J. Weitzman, "Marital property: Its transformation and division in the United States", in Economic Consequences of Divorce, the international perspective, 131-134.

$25 \quad$ [1985] 66 N.Y 2d. 576. 
assignable personal privilege which was agreed by the intermediate court.

The New York Court of Appeals nevertheless, by referring to the New York's Domestic Relations Law as well as prior cases dealing with the definition and distribution of intangible properties like the case of Majauskas v. Majauskas ${ }^{26}$ and Arvantides v. Arvantides, ${ }^{27}$ upheld the original verdict that a professional license does constitutes marital property. The court said:

In this case, nearly all of the parties' nine year marriage was devoted to the acquisition of the plaintiff's medical license and the defendant played a major role in the project. She worked continuously during the marriage and contributed all of her earnings to their joint effort, she sacrificed her own educational and career opportunities, and she traveled with the plaintiff to Mexico...these contributions represent investments in the economic partnership of the marriage and that the product of the parties' joint efforts, the professional license, should be considered marital property. ${ }^{28}$

The quotation proves that the court explicitly acknowledged the importance of the partnership theory of marriage which practically human capital also serves as one of the best examples. Additionally, this is also is consistent with the intent and spirit of division of matrimonial property i.e. as rightly emphasised by Weitzmanis to recognise each spouse's contribution to the acquisition of the matrimonial property. ${ }^{29}$ As to the valuation, the court in this case by applying "future income stream" did not value the wife's contribution based on the funds provided but on the enhanced earnings that it produced. Since the investment by the wife resulted in her husband obtaining his medical degree, the court based the enhanced earnings

\footnotetext{
$26 \quad$ [1984] 61 N.Y. 2d 481; 436 N.E 2d 15.

$27 \quad$ [1985] 64 N.Y. 2d 1033; 478 N.E. 2d 199.

$28 \quad$ [1985] 66 N.Y 2d. 576. at pp. 585-586.

29 Lenore J. Weitzman, "Marital property: Its transformation and division in the United States" in Lenore J. Weitzman and Mavis Maclean (edit), Economic consequences of divorce, the international perspective, 87 .
} 
on the difference between the college graduate's income with a bachelor's degree and one with a medical degree. ${ }^{30}$ Similarly, the court in the case of Hougie $v$ Hougie ${ }^{31}$ also decided that a husband's "enhanced earning capacity" as an investment banker was considered as matrimonial property and subject to division upon divorce.

The principle established in $\mathrm{O}^{\prime} \mathrm{Brien}^{32}$ was later extended to celebrity divorces. Courts have to decide whether celebrity status based on being an actor, as well as other types of celebrities such as athlete and musicians can be considered as property. While the investment in human capital occurs in the professional degree through educational institutions, the same equally occurs in acquiring celebrity status through training. ${ }^{33}$ The first case that recognised celebrity status as marital property is Golub v. Golub ${ }^{34}$ which involved the renowned and celebrated film and television actress and model, Marisa Barenson. The New York Supreme Court in this case held that the increase in the value of model and actress Marisa Barenson's career was marital property subject to equitable distribution in her divorce from her attorney husband, A. Richard Golub. The court also emphasised that the skills of artisan, actors, professional athletes or any person whose expertise in his or her career has enable him or her to become an exceptional wage earner should be valued as marital property and subject to division accordingly.

Few other cases holding that celebrity status is marital property subject to division at divorce occurred in the divorce of opera singer Fredicia von Stade Elkus and her husband Peter Elkus in the case of Elkus $v$ Elkus. ${ }^{35}$ The appellate court held that the analysis in the O'Brien case was equally applicable to Ms. Von Stade's celebrity career. Even though the wife argued that her career was not marital property as she had already become successful before her marriage to Mr. Elkus, the court rejected the argument by noting the increase in her increment after the marriage. This impliedly indicates

$30 \quad$ Allen M. Parkman, "Human capital as property in celebrity divorces", Family Law Quarterly, No. 1vol.29 (1995): 141,153.

$31 \quad 689$ N.Y.S 2d 490 (N.Y.A.D. 1 Dept).

$32 \quad$ [1985] 66 N.Y. 2d. 576.

33 Allen M. Parkman, "Human capital as property in celebrity divorces", Family Law Quarterly, No. 1vol.29 (1995) 141: 48.

$34 \quad$ [1986] 527 N.Y.S. 2d 946.

35 [1991] 572 N.Y.S. 2d 901. (App. Div.) 
that the husband's involvement in her career clearly contributed to the increase in its value and consequently constitutes marital property.

The above cases prove that human capital as matrimonial property was not only restricted to licensed professions. What concerns the court is the contribution made by the contributing spouse in enhancing the earning capacity of the spouse. This is further emphasised by the "economic partnership" concept of marriage whereby anything acquired throughout the marriage will be shared should the marriage end.

The above finding corresponds to the idea proposed by Weitzman ${ }^{36}$ who rightly observes that the reason why the earning capacity should be divided upon divorce is basically based on two premises. The first is simply because they are joint effort property. Most married couples acquire earning capacity in the same manner that they acquired the other property that the court recognises as matrimonial property. The fact that it is the product of the couple's joint efforts and resources is undeniable. For example, if the husband is the sole-wage earner. It is likely that the wife will devote time, energy and money to build the husband's career. In fact the traditional division of labor does benefit the family, specifically the husband's earning capacity. The wife's work at home frees the husband to concentrate on his work and the acquiring of property for the family. As a result of the couple's united efforts, the husband's earning capacity will be enhanced. It can be safely said that both of them have invested their joint resources in the 'human capital' of the bread-winning spouse.

The issue is often no less significant in a two-income family where both the husband and wife are working. Although it is undeniable fact that both enter into a marriage with their distinct human capital, it is common for them to give priority to one spouse's career and to defer his or her own career opportunities. More than that, they even willing to accept a temporary reduction in their standard of living to support the other spouse in the expectation that both will share the income to be derived from the other spouse and to share the benefits together. ${ }^{37}$

Lenore J. Weitzman, "Marital property: its transformation and division in the United States, in Economic consequences of divorce, the international perspective, 105.

37 Preger S., "Sharing principles and the future of Marital Property Law", UCLA Law Review, No. 1 vol. 25(1997) 1: 6. 
The second is that it is impossible to have a fair division of property if these assets are not divided. Since the major wealth of most divorcing couples is these assets, to exclude them from the pool of matrimonial property is to skew the apportionment in favors of the primary working spouse who is usually the husband. As a result, it will produce an unfair division of matrimonial property.

\section{EARNING IN BUSINESS}

Other than remuneration, personal earning in business could also be applied in scope of future earnings. In business, the capital invested in the business are meant to be expanded in future and as such, from the beginning, it is highly anticipated by all parties invested in the business that their interest in the business shall increase than what they invested initially.

In Sivanes a/l Rajaratnam v Usha Rani a/p Subramaniam ${ }^{38}$, the Court of Appeal upheld the decision of the High Court that upon the divorce, the wife was entitled to a share of the clinic as matrimonial property because the wife had contributed to the setting up of the clinic by, among others:

(i) Standing as guarantor for banking facilities

(ii) Selling the family car to tide over the difficult period and

(iii) Utilising joint savings in the opening of the clinic

Another interesting case law to highlight is Boto' binti Taha $v$ Jaafar bin Muhamed ${ }^{39}$, whereby at the time of the marriage, the plaintiff-wife worked as a coffee-shop assistant and the defendanthusband carried on a fishmonger business in Dungun. The business of the defendant prospered and during the marriage he bought the matrimonial home, a piece of land, four fishing boats, fishing nets and a fish stall. The marriage ended in a divorce and upon divorce the defendant only paid the plaintiff her maintenance for the period of eddah. The plaintiff applied to High Court for a declaration that she was entitled to a one-half share in all the properties acquired during

\footnotetext{
$38 \quad$ [2002] 3 MLJ 273.

$39 \quad$ [1985] 2 MLJ 98.
} 
her marriage to the defendant and to one-half share of all the income derived from the properties since their divorce. The court held that matrimonial property is based on customs practiced by the Malays and rests upon the legal recognition of the part played by a divorced spouse in the acquisition of the relevant property and in improvements done to it, in cases where it was acquired by the sole effort of one spouse only. It is due to this joint effort or joint labour that a divorced spouse is entitled to a share in the property. The fact that the plaintiff accompanied the defendant in his business trips and giving up employment because of the marriage must amount to her joint efforts in the acquisition of those properties. Interestingly, the court further held in this case that even though the plaintiff did not take direct part in the defendant's fish business, her constant companionship was responsible for the defendant's peace of mind which enabled him to function effectively as a businessman. The evidence shows that she was helping the plaintiff's business indirectly as a partner in his business trips. As such, the properties which are the subject of the present suit are matrimonial property.

\section{ANALOGY}

Applying the analogy of a commercial partnership into a marriage, the court explicitly acknowledged the importance of the spousal partnership during the marriage which gives rise to rights of the partners to share all benefits that arise out of the partnership. Under the partnership law, all benefits which arise during the partnerships must be disclosed and shared between the partners, either in equal proportion or as agreed between the partners. This means, if the future earnings of the divorced parties were accumulated during the marriage, it should be claimable as matrimonial property. Such approach is consistent with the intent and spirit of division of matrimonial property, i.e. recognition of each spouse's contribution to the acquisition of the matrimonial property. Lord Denning in Wachtel v. Wachte ${ }^{40}$ held that matrimonial assets should refer to those things, which are acquired by one or the other or both of the parties. This must be coupled with the intention that it should be continuing provision for them and their children during their joint lives, and used

40 [1973] Fam. 72, at p.90. 
for the benefit of the family as a whole. The judge divides the matrimonial assets into two parts; assets "of a capital nature" such as the matrimonial home and its furniture and "revenue producing nature" which include the earning power of husband and wife. The finding of Lord Denning conforms with the decision of Lord Diplock in the case of Pettit v. Pettit ${ }^{41}$ where matrimonial property or family assets means "property whether real or personal, which has been acquired by either spouse in contemplation of their marriage or during its subsistence and was intended for the common use and enjoyment of both spouses or their children". ${ }^{42}$ The above cases show that the English courts by using the word "family assets", describe matrimonial property as property in which both spouses should have some interest either because of the way in which it was acquired or because of the manner in which it was used. ${ }^{43}$

As regards the valuation, in determining the entitlement to "future income stream", the court generally, did not value the contribution based on the funds provided but on the enhanced earnings that it produced. Since the investment by the spouse/s resulted to the accumulation of the future earning, the court calculation was made based on the difference between the enhanced earnings and the initial earning of the parties prior to the accumulation of the earning due to the marriage. For example, the difference between the college graduate's income with a bachelor's degree and one with a medical degree. ${ }^{44}$ Similarly, the court in the case of Hougie $v$ Hougie ${ }^{45}$ also decided that a husband's "enhanced earning capacity" as an investment banker was considered as matrimonial property and subject to division upon divorce.

\section{$41 \quad$ [1970] AC 777.}

42 Ibid, at p. 819.

43 See the English Law Commission (Family Property Law), the Law Commission Published Working Paper, No. 42, para 0.24 at p. 15.

44 Allen M. Parkman, "Human capital as property in celebrity divorces", Family Law Quarterly, vol. 29(1) (1995) 141: 153. 689 N.Y.S 2d 490 (N.Y.A.D. 1 Dept). 


\section{CONCLUSION}

Based on the above discussion, it is submitted that human capital or earning capacity should be recognised as a matrimonial property and subject to division upon divorce. This is principally based on the fact that both spouses do contribute to its accumulation either directly or indirectly. The same principle should be equally applicable to any claim on future interest in business or investment. The fact that its valuation and assessment is rather complex might not prevent the court from dividing it, as Carrigan J. rightly said, "the difficulty of valuing the enhanced earning capacity does not justify denying the wife's claim". ${ }^{46}$ At the very least, if the court decided not to value or recognise it as matrimonial property per se and subject to division, it is urged that it should be taken into consideration in distributing other property. Or else, unjust result may ensue.

$46 \quad$ Per Carrigan J. dissenting, in the case of Graham v. Graham [1978] 574, P.2d 75, at p. 78. 